\title{
Acute and sub-acute toxicity study of bacterial signaling inhibitor Solanum torvum root extract in Wister rats
}

\author{
Kayeen Vadakkan®
}

\begin{abstract}
Background: Solanum torvum root extract is used to treat Asthma, Diabetes, and hypertension by Garo tribal healers of India and Bangladesh. Root tea is used to treat cough and fever by Attapadi tribal people of Kerala, India. The in vivo toxicological effects of Solanum torvum root extract was assessed by acute and sub-acute toxicity studies according to the OECD (Organisation for Economic Co-operation and Development) guidelines and per the guidance of Committee for the Purpose of Control and Supervision of Experiments on Animals (CPCSEA), Ministry of Environment and Forest, government of India.

Results: A single dose of Solanum torvum root extract (300 mg/kg, $600 \mathrm{mg} / \mathrm{kg}$ and $1200 \mathrm{mg} / \mathrm{kg}$ ) was administrated daily for 14 days to estimate acute toxicity whereas subjects were treated for 28 days to assess the sub-acute toxicity. General functional behaviors, Physiological, histological, biochemical and hematological parameters were observed to understand the effect of extract upon study animal. All the study subjects were alive after the study period after acute and sub-acute toxicity assay. Functional and behavioral characteristics such as body position, respiration, clonic involuntary movement, tonic involuntary movement, palpebral closure, approach response, touch response, pinna reflex and tail pinch response; palpebral closure, lacrimation, salivation, piloerection, pupillary reflex, abdominal tone, limb tone, when held in hand were also found to be normal. Histological, biochemical and hematological parameters were also normal compared that with untreated group.

Conclusions: The acute and sub-acute toxicological analysis of Solanum torvum root extracts up on Wister rats suggested that there are no any dose response relation between extract administrated and toxicity, therefore there are no toxic effect by STRE, however more enlightenment regarding toxicity due to prolonged exposure can only be understood from chronic toxicity analysis.
\end{abstract}

Keywords: Acute toxicity, Solanum torvum, Sub-acute toxicity

\section{Background}

Ethnobotanical dependent medication is not a new scenario, it has been widely practiced since the inception of mankind. The World Health Organization (WHO) reports that $70-80 \%$ of world population exploit alternative medicine in any of its form [1]. Solanum torvum is commonly known as Turkey berry which is widely distributed in India, tropical Africa, Southern Asia, and South America and widely used as a food ingredient [2]. It has an immense ethnopharmacological importance as it display

Correspondence: kayeenvadakkan@gmail.com

Department of Biotechnology, St. Mary's College, Thrissur, Kerala 680020, India wide spectrum of pharmacological activities such as antiinflammatory, antioxidant, antidiabetic, antihelmintic, anti- hyperlipidemic and nephroprotective activities [3]. Solanum torvum root extract is used to treat Asthma, Diabetes, hypertension Garo tribal healers of India and Bangladesh [4]. Root tea is used to treat cough and fever by Attapadi tribal people of Kerala, India.Recently it is also observed that Solanum torvum root extract could down regulate bacterial quorum sensing [5] which could elevate the medicinal value of plant.

Quorum sensing is a bacterial population depended mechanism which enables the bacterial community to inductee functions related to virulence and infection. Several bacterial traits such as pigment production, biofilm
Springer Open

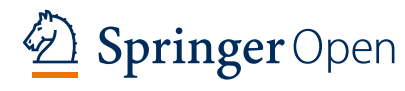

(c) The Author(s). 2019 Open Access This article is distributed under the terms of the Creative Commons Attribution 4.0 International License (http://creativecommons.org/licenses/by/4.0/), which permits unrestricted use, distribution, and reproduction in any medium, provided you give appropriate credit to the original author(s) and the source, provide a link to the Creative Commons license, and indicate if changes were made. 
formation, swarming motility, toxin production and exozyme synthesis are found to be organized by quorum sensing [6]. Depending upon the signalling pathway quorum sensing systems have been categorized into three, acyl homoserine lactone (AHL) mediated quorum sensing which is seen only in gram negative bacteria, LuxS controlled communication which is seen in both gram negative and gram positive bacteria and peptide induced signalling which regulate communication in gram positive bacteria [7]. Typical quorum sensing system in gram negative bacteria contains two integrands; an autoinducer synthesizing gene and an autoinducer receptor cum transcriptional activator. Bacterial communication is highly intra-species specific due to peculiar receptor binding sites that recognize only precise AHLs thus signals produced by one species will not disturb the mechanism of other [8]. By suppressing bacterial quorum sensing it is possible to inhibit all the subsequent virulent mechanisms by the pathogen which in turn silence it in a host system therefore assist host defence mechanism for successive clearance.

Inhibition of quorum sensing is collectively called as quorum quenching wherein, the signalling mechanism is repressed without effecting the bacterial growth. Due to this the virulent properties of pathogens are suppressed, as a result host defence mechanism gets adequate exposure and time for effective immune clearance [9]. Signal mediated bacterial communication could be stopped by the employment of different techniques depending upon the mechanism of signalling in organism and the site of reaction. These inhibitory methods are broadly categorized into two groups such as enzymatic inhibition and non-enzymatic inhibition. Enzymatic inhibition includes the degradation of signalling molecule by the usage of enzymes like lactonase, acylase, oxidoreductase etc; which will consecutively disable the signalling pathway [10]. Non-enzymatic bacterial silencing can be attained by approaches like signal synthesis inhibition, competitive or allosteric inhibition of signal binding to response gene and through blocking signal reception by response gene through modification and conformational changes of signalling molecule structure [11].

Even after such immense understanding about vital importance of bacterial quorum sensing inhibition, till date only a very limited number of quorum quenching agents have been successfully adopted to the clinical level due to their low biocompatibility and less understanding about in vivo toxicity. This insists the research community to find a nontoxic remedial agents by the exploitation of ethnopharmacology and its subsidiaries, as ethnobotanical agents has

\section{Effect of STRE upon body weight (males)}

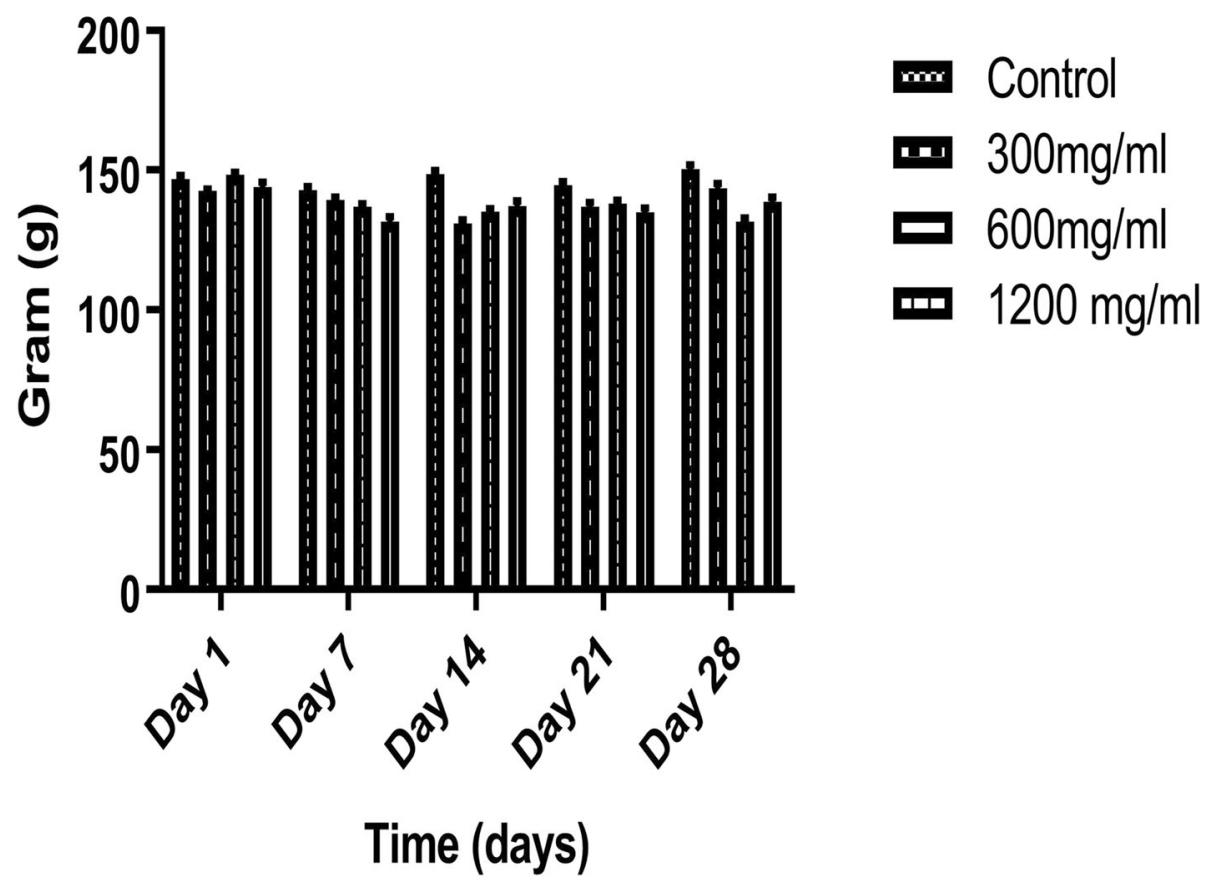

Fig. 1 Effect of STRE on bodyweight of male subjects. Values are expressed as mean \pm SEM Statistical significance (p) calculated by one way ANOVA followed by dunnett's $(n=6)$ 


\section{Effect of STRE upon body weight (female)}

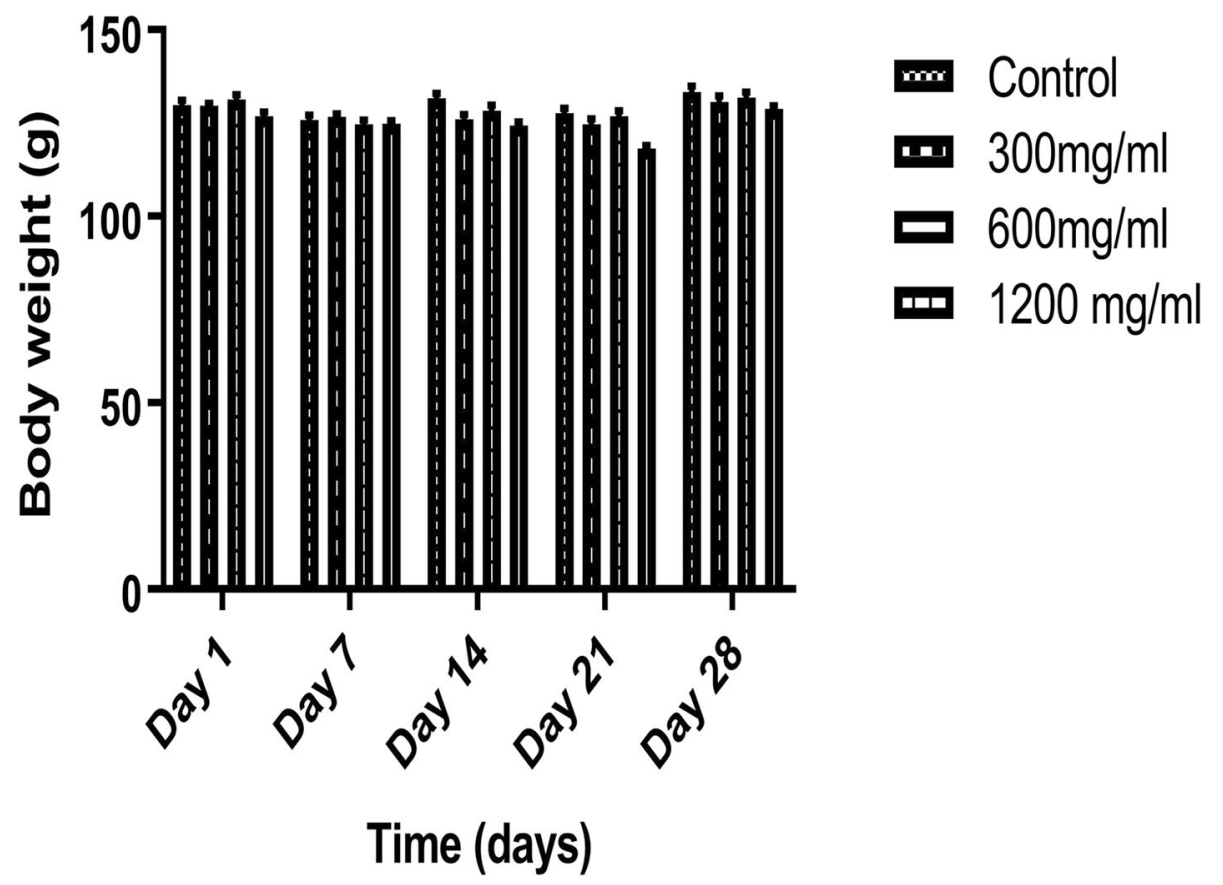

Fig. 2 Effect of STRE on bodyweight of female subjects. Values are expressed as mean \pm SEM Statistical significance (p) calculated by one way ANOVA followed by dunnett's $(n=6)$

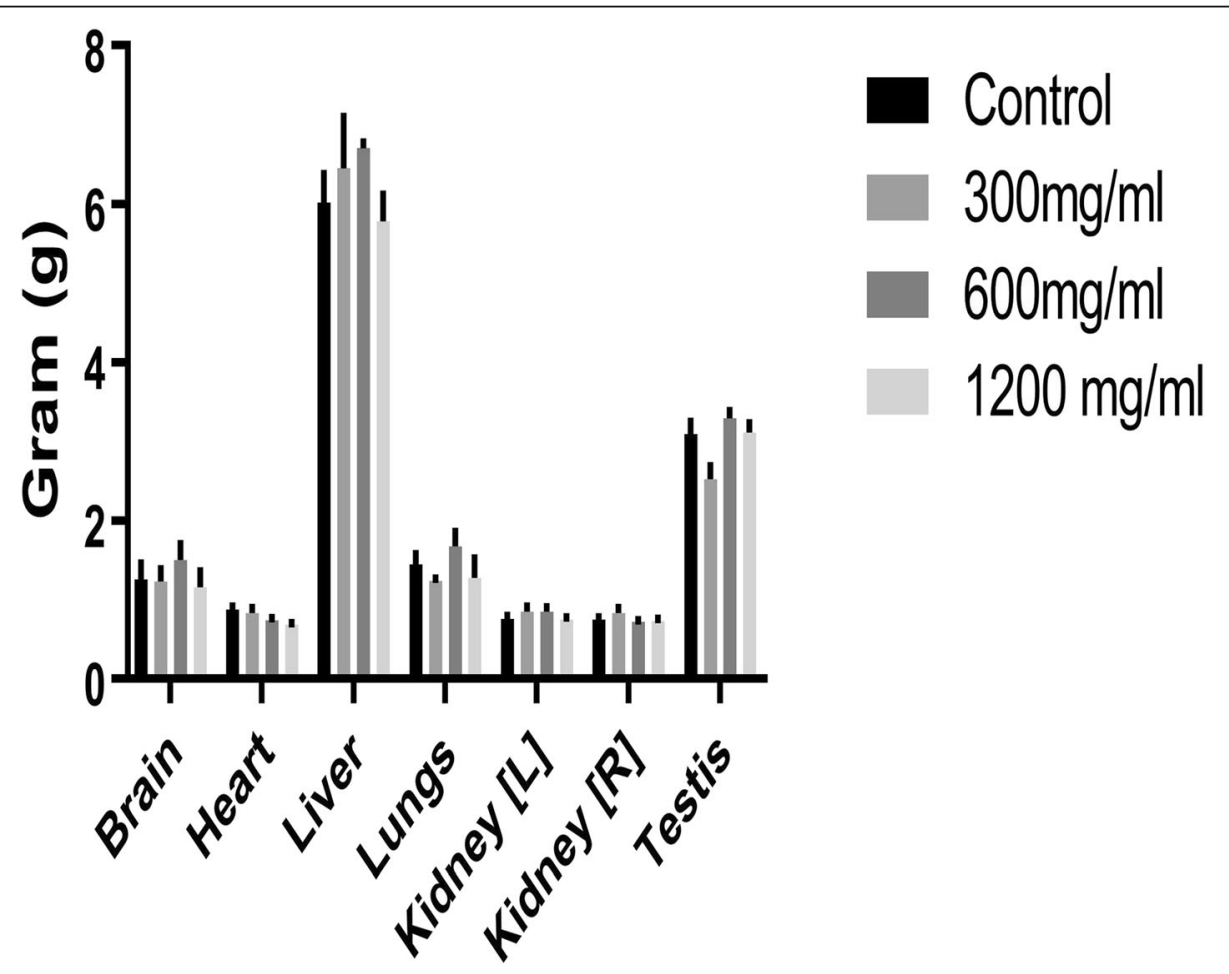

Fig. 3 Effect of STRE on organ weight of male subjects. Values are expressed as mean \pm SEM Statistical significance ( $p$ ) calculated by one way ANOVA followed by dunnett's $(n=6)$. 
apprehended the attention with their elevated biocompatibility over its synthetic counterparts. Despite of its much appreciated biocompatibility vast exploitation of ethnomedicine have raised several questions upon its anonymous toxicity. Therefore it is important to understand the toxicological effects of ethanobotanical agents for its indisputable usage. Similarly there are no data available upon safety and toxicity of Solanum torvum root extract, therefore in this present study we are analysing the acute and sub chronic toxicity of Solanum torvum root extract in Wister rats and there by eliminate the chaos over its side effects.

\section{Methods}

Sample collection and preparation of extract samples Solanum torvum was collected from Thrissur District, Kerala, India (Latitude: 10.5890536 and Longitude: 76.0971808) during August 2015. The identity of sample was authenticated by $\mathrm{rbcL}$ gene sequencing and nucleotide blast, later submitted in NCBI under the accession number KU599936. Root of collected plant samples were washed and chopped into small pieces later dried in sunlight for six days until all moisture content was removed. Subsequently dried sample was grinded into fine power and boiled in water for three hours at $100^{\circ} \mathrm{C}$. The resulting suspension was filtered which was further concentrated and dried under controlled laboratory conditions to obtain STRE (Solanum torvum root extract). Obtained STRE was dissolved in distilled water to make concentrations of toxicity evaluation [12].

\section{Experimental animals and maintenance}

The test animals (Wister rats, body weight ranging within 131.56-172.69g) were housed under standard laboratory conditions, air-conditioned with adequate fresh air supply (Air changes 12-15 per hour), room temperature $22 \pm 30{ }^{\circ} \mathrm{C}$, relative humidity $30-70 \%$, with $12 \mathrm{~h}$ light and $12 \mathrm{~h}$ dark cycle. These animals were selected because of the recommended rodent species for oral studies as per followed guideline and availability of Animals 8-12 weeks old male and female rats were selected after physical and behavioral examination. The body weight range was fallen within $\pm 20 \%$ of the mean body weight at the time of Randomization and grouping. The rats were housed in Polypropylene cages, provided with food and water ad libitum. The experimental protocol was approved by Institutional Animal Ethical Committee (KMCRET/ Ph.D./17/2017-17, dated 28-May-2016) as per the guidance of Committee for the Purpose of Control and Supervision of Experiments on Animals (CPCSEA), Ministry of Environment and Forest, government of

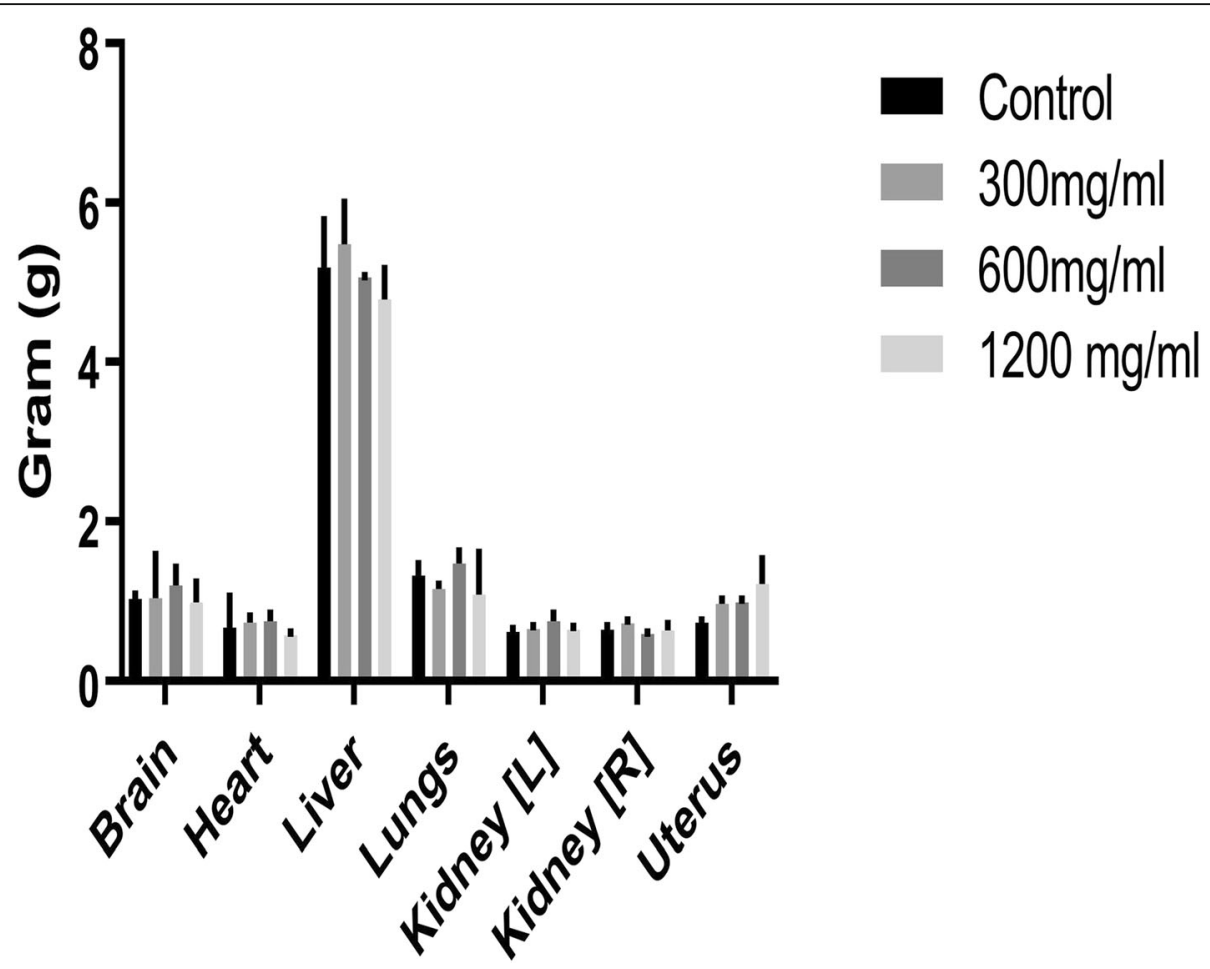

Fig. 4 Effect of STRE on organ weight of female subjects. Values are expressed as mean \pm SEM Statistical significance (p) calculated by one way ANOVA followed by dunnett's $(n=6)$. 
India. The animals were acclimatized for a period of 3 days to laboratory conditions and observed for clinical signs daily. Body weight, clinical signs, and mortalities were observed and measured regularly; General observations such as food intake, salivation, muscular weakness, and reflexes were analyzed.

\section{Experimental Design of Animal Model}

Rats were randomly divided into four groups each containing twelve subjects (6 males and 6 females); Group 1 was considered as control group in which no drug was administrated. Group 2 was selected to analyze the effects of low concentration $(300 \mathrm{mg} / \mathrm{kg}$ ) drug. A medium dose of $600 \mathrm{mg} / \mathrm{kg}$ body weight was administrated in group 3 to find out the toxic effect of STRE. Group 4 was used to identify the toxic effect of high dose STRE $(1200 \mathrm{mg} / \mathrm{kg})$. Solanum torvum root extract was added in distilled water and completely dissolved for oral administration. The dose was prepared of a required concentrations. The test item was administered orally to each rat as single dose using a needle fitted on to a disposable syringe of appropriate size at the following different doses. The concentration was adjusted according to its body weight. The volume was not exceeding $10 \mathrm{ml} / \mathrm{kg}$ body weight. Variability in test volume was minimized by adjusting the concentration to ensure a constant volume at all dose levels.

\section{Evaluation acute toxic effect of STRE}

To determine the acute toxic effect of STRE all animals were observed for any kind of abnormal clinical signs and behavioral changes adhering to the OECD Guidelines No. 423 [13]. The appearance, change and disappearance of these clinical signs, if any, were recorded for approximately 1.0, 3.0 and $4.0 \mathrm{~h}$ post-dose on day of dosing and once daily thereafter for 14 days. The cageside observation was included changes in skin, fur, eyes and mucous membranes, occurrence of secretions and excretions. Autonomic activity like lacrimation, piloerection, pupil size and unusual respiratory pattern, changes in gait, posture, response to handling, presence of clonic or tonic movements, stereotypes like excessive grooming and repetitive circling or bizarre behavior like self-mutilation, walking backwards etc. were observed [14]. At the 14th day, sensory reactivity to stimuli of different types (e.g. auditory, visual and proprioceptive stimuli) was conducted. Auditory stimuli responses were measured by clicker sound from approximately $30 \mathrm{~cm}$ to the rats; visual stimuli response were measured with the help of shining

\section{Effect of STRE upon food intake (males)}

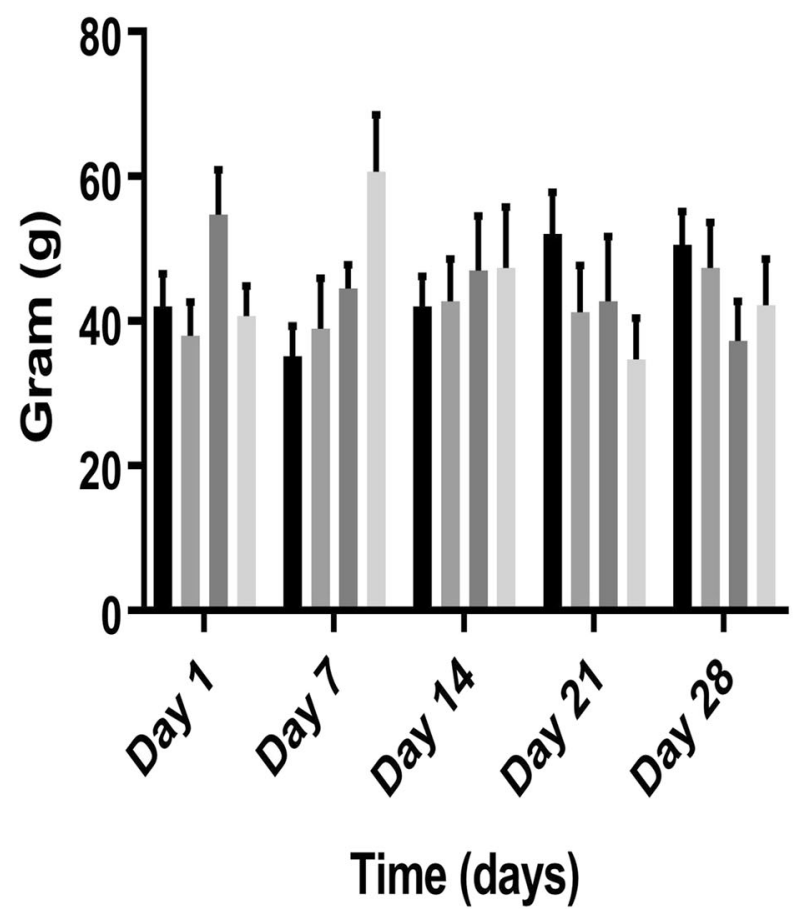

- Control

- $300 \mathrm{mg} / \mathrm{ml}$

- $600 \mathrm{mg} / \mathrm{ml}$ $1200 \mathrm{mg} / \mathrm{ml}$

ANOVA followed by dunnett's $(n=6)$ 
pen light in the eye of rats and placing a blunt object near to the eye of rats. Response to proprioceptive stimuli was measured by placing anterior/dorsal surface of animals paw to the table edge. All animals were observed daily once for mortality and morbidity at approximately 1.0, 3.0 and $4.0 \mathrm{~h}$ post dose on day of dosing and twice daily (morning and afternoon) thereafter for 14 days [15].

\section{Assessment of sub-acute toxicity of STRE}

Subjects were observed for 28 days for the assessment of sub-acute toxic effect of Solanum torvum root extract by quotidian oral administration [16] .All the subjects were observed at least twice a day with the purpose of recording any symptoms of ill- health or behavioral changes such as changes in skin and fur, activity of eyes, respiration rate, circulatory, somatomotor activity. Prior to the beginning of treatment, and daily, the food intake of each cage was recorded for study period of 28 days and the mean weekly intake per rats was calculated. Water intake was checked by visual observation during the Study. In addition, the water consumption in each cage was measured daily. The body weight of each rat was recorded one week before the start of treatment, and during the course of the treatment on day 1 (initial day of drug administration), 7, 14, 21 and 28 (day of sacrifice). The mean weights for the different groups and sexes were calculated from the individual weights [17]. On completion of the study period subjects were sacrificed by ether inhalation. A full autopsy was performed on all animals which included examination of the external surface of the body, all orifices, cranial, thoracic and abdominal cavities and their contents both in situ and after evisceration. After the macroscopic examination Brain, Heart, Liver, Lungs, Kidney (right and left), Testis (males), Uterus (females) were weighed after separating the superficial fat [18].

\section{Hematological analysis}

On 28th day of treatment, samples of blood were withdrawn from the orbital sinus of subjects from each group, under light ether anesthesia after fasting for 16 h. The blood samples were collected in tubes containing EDTA as an anticoagulant. Later the hematological parameters such as red blood cell count (RBC), white blood cell count (WBC), hemoglobin concentration (HB), Percentage of Polymorphs, Lymphocytes and Monocytes were calculated [19].

\section{Serum biochemistry analysis}

The collected blood samples were allowed to remain in tubes without anticoagulant for $45 \mathrm{~min}$ after which it was centrifuged at $3500 \mathrm{rpm}$ for $10 \mathrm{~min}$ to separate

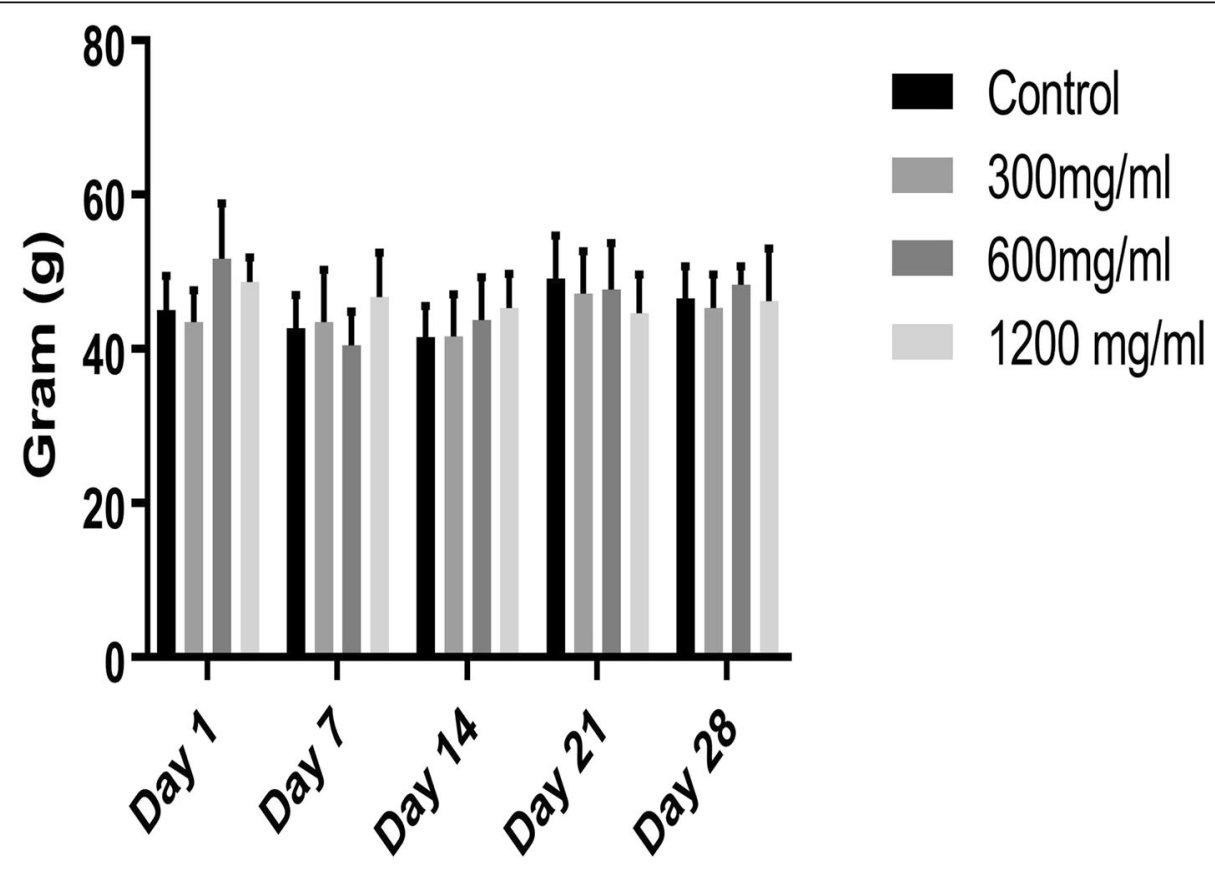

Time (days)

Fig. 6 Effect of STRE on food intake of female subjects. Values are expressed as mean \pm SEM Statistical significance (p) calculated by one way ANOVA followed by dunnett's $(n=6)$ 
serum. The separated serum used to evaluate biochemical parameters like SGOT, SGPT, ALP, total bilirubin, creatinine, uric acid, Sodium, Calcium, and Phosphorus [20].

\section{Histopathological analysis}

Histological analysis was done to evaluate the tissue level effect of STRE upon organs of subjects. Organs from subjects were collected and washed in $0.9 \%$ saline solution which was fixed in formaldehyde-calcium solution. Sections of $5 \mu \mathrm{m}$ thickness was prepared and stained with hemotoxylin and eosin (HE). General structure of tissue, degenerative changes, necrosis and inflammation were analyzed in $40 \mathrm{X}$ photomicrography [21].

\section{Statistical analysis}

Hematological and biochemical data were expressed as mean \pm standard error of the mean (SEM). Data were submitted to analysis of variance (One-Way ANOVA) followed by Newman-Keuls multiple comparison test. Food and water intake, Organ weight and body weight were expressed as mean \pm SEM followed by Dunn's post-test. The software GraphPad Prism 7.0 (GraphPad Software, USA) was used for statistical analysis. $P$ values $<0.05$ were considered statistically significant.

\section{Results}

Acute toxicity assessment on mortality and functional behavior

From acute toxicity study it was observed that the administration of STRE at a dose of varying from 0 to $1200 \mathrm{mg} / \mathrm{kg}$ body weight of study subject did not produce drug-related toxicity and mortality. So No-Observed-Adverse-Effect- Level (NOAEL) of STRE at $1200 \mathrm{mg} / \mathrm{kg}$. There were no any sign of mortality in any subjects of study groups as all the rats survived the study period. Functional and behavioral observations done on home cage activities such as body position, respiration, clonic involuntary movement, tonic involuntary movement, palpebral closure, approach response, touch response, pinna reflex and tail pinch response were seen normal. Similarly functional and behavioral observations such as reactivity, handling, palpebral closure, lacrimation, salivation, piloerection, pupillary reflex, abdominal tone, limb tone, when held in hand were also found to be normal.

\section{Sub-acute toxic effect of STRE on mortality and general physiological parameters}

Sub-acute toxicity analysis suggested that administration of STRE did not induce any kind of toxic effect or changes in regular behavioral aspects of subjects.

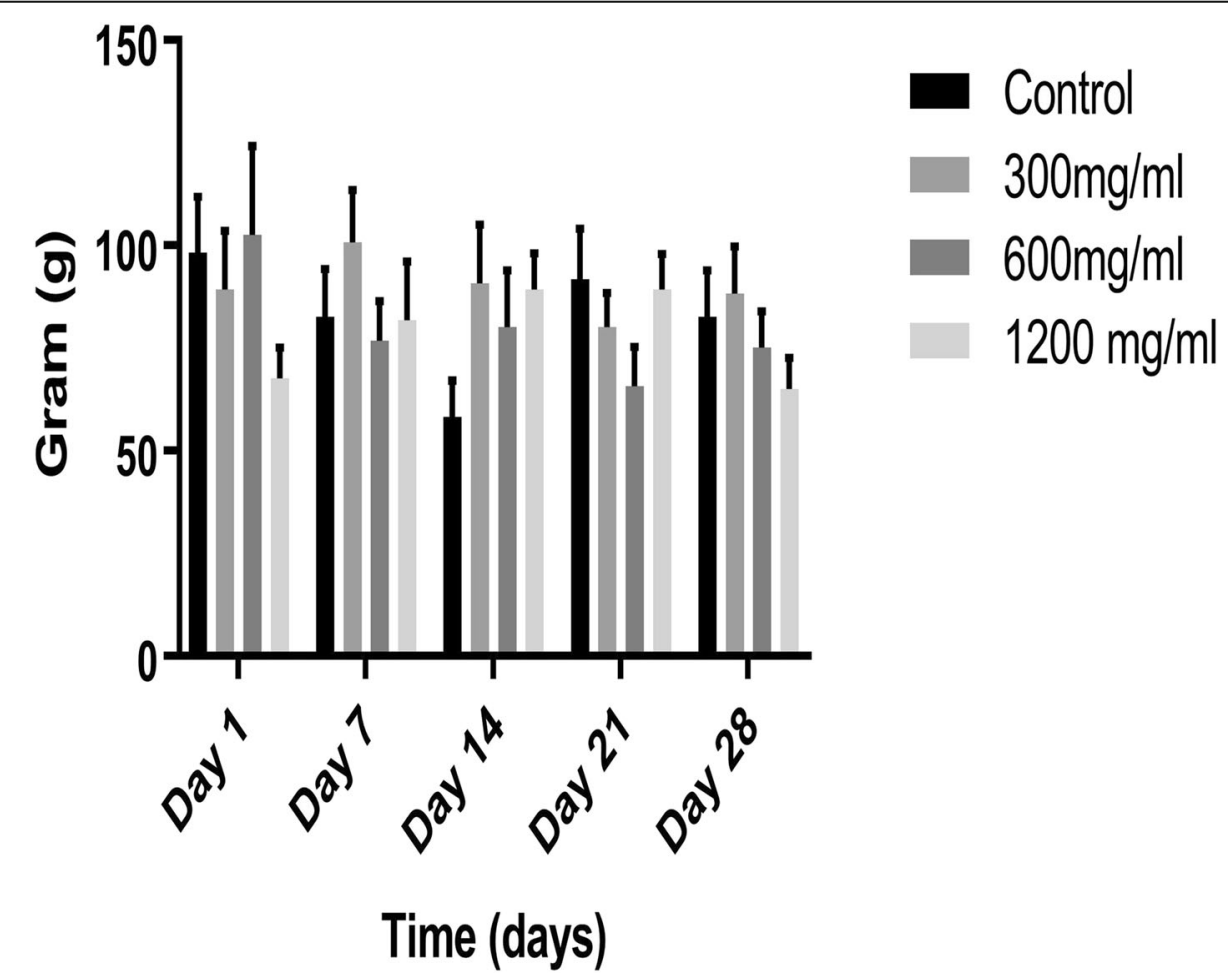

Fig. 7 Effect of STRE on water intake of male subjects. Values are expressed as mean \pm SEM Statistical significance (p) calculated by one way ANOVA followed by dunnett's $(n=6)$ 


\section{Effect of STRE upon water intake (Females)}

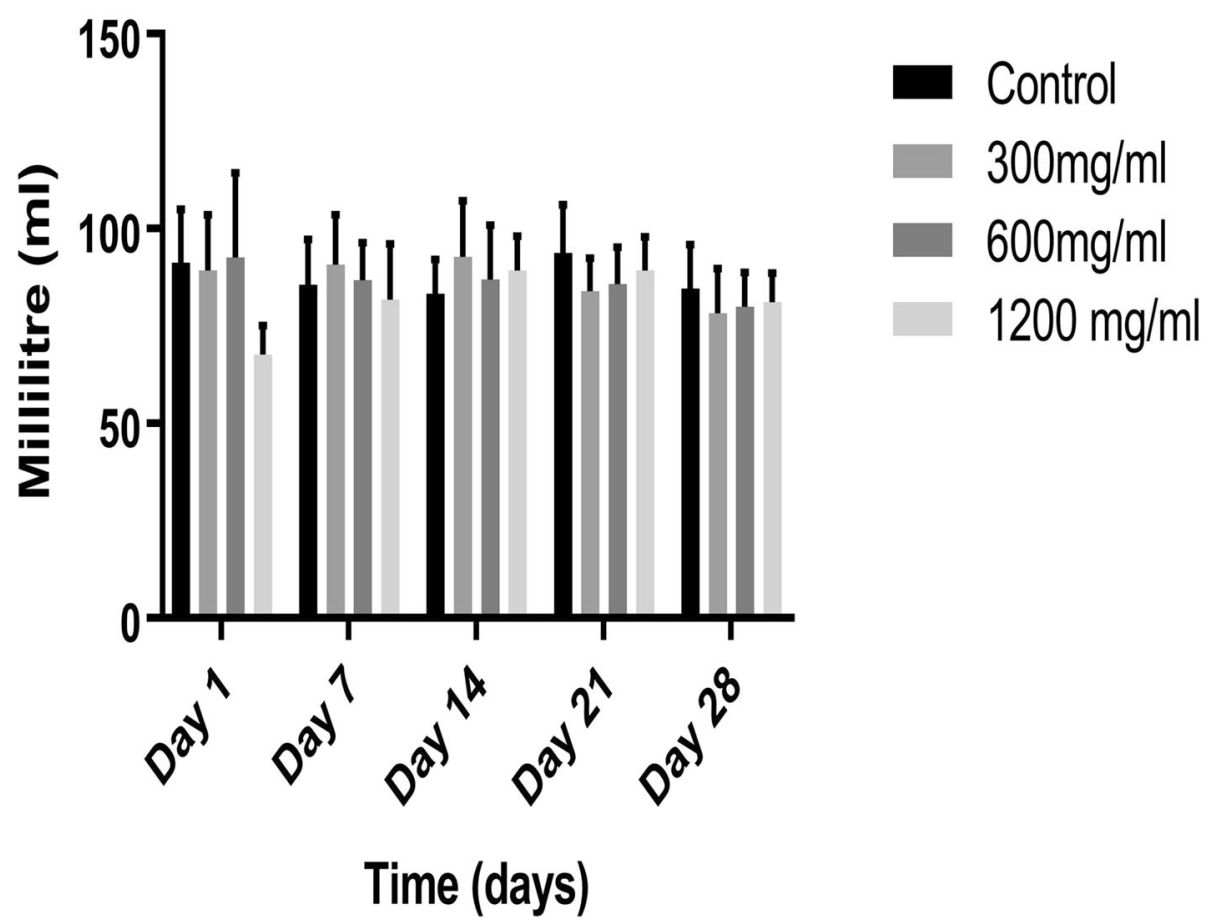

Fig. 8 Effect of STRE on water intake of female subjects. Values are expressed as mean \pm SEM Statistical significance (p) calculated by one way ANOVA followed by dunnett's $(n=6)$

After 28 days of treatment there were no any mortality reported which suggested that STRE is safe in all the tested concentrations. Treatment with STRE did not possess any abnormalities in the body weight of male subjects (Fig. 1) and female subjects (Fig. 2). Body weight evaluation clearly indicated that there is no any significant relationship between concentrations of STRE administrated upon variations in body weight. Similar trend was also seen in the individual organ weight of study subjects (Figs. 3, 4), observations clearly suggested that there is no correlation between orally administrated STRE upon organ weight as there was no any significant fluctuations observed compared that with control group. Effect of Solanum torvum upon food intake (Figs. 5, 6) and water intake (Figs. 7,8 ) was also found to be null as the parameters studied were matching that with untreated group.

\section{Analysis of hematological parameters}

Hematological parameters such as red blood cell count (RBC), white blood cell count (WBC), hemoglobin concentration (HB), Percentage of Polymorphs, Lymphocytes and Monocytes were found to be unaffected by the treatment of STRE (Table 1).

Table 1 Hematological analysis of study subjects. Values are expressed as mean \pm SEM Statistical significance (p) calculated by one way ANOVA followed by Newman-Keuls multiple comparison test

\begin{tabular}{|c|c|c|c|c|c|c|c|c|}
\hline \multirow[t]{2}{*}{ Group } & \multicolumn{2}{|l|}{ Control } & \multicolumn{2}{|l|}{$300 \mathrm{mg} / \mathrm{kg}$} & \multicolumn{2}{|l|}{$600 \mathrm{mg} / \mathrm{kg}$} & \multicolumn{2}{|l|}{$1200 \mathrm{mg} / \mathrm{kg}$} \\
\hline & Male $(n=6)$ & Female $(n=6)$ & Male $(n=6)$ & Female $(n=6)$ & Male $(n=6)$ & Female $(n=6)$ & Male $(n=6)$ & Female $(n=6)$ \\
\hline $\mathrm{RBC}\left(\mathrm{X} 10^{6} / \mu \mathrm{L}\right)$ & $6.573 \pm 0.119$ & $4.536 \pm 0.113$ & $6.39 \pm 0.3035$ & $5.689 \pm 0.482$ & $6.853 \pm 0.6894$ & $4.730 \pm 0.351$ & $6.092 \pm 0.361$ & $5.8 \pm 0.730$ \\
\hline WBC $\left(X 10^{3} / \mu \mathrm{L}\right)$ & $5.557 \pm 1.531$ & $4.703 \pm 1.972$ & $6.478 \pm 0.5783$ & $5.771 \pm 1.093$ & $5.051 \pm 1.007$ & $3.516 \pm .747$ & $5.948 \pm 0.3756$ & $4.047 \pm 1.318$ \\
\hline $\mathrm{HB}(\mathrm{g} / \mathrm{dl})$ & $12.507 \pm 0.5859$ & $11.720 \pm 0.703$ & $12.299 \pm 0.8963$ & $10.248 \pm 1.091$ & $12.83 \pm 1.683$ & $11.330 \pm 0.593$ & $12.032 \pm 0.809$ & $11.741 \pm 0.750$ \\
\hline Polymorphs (\%) & $7.333 \pm 2.740$ & $6.096 \pm 2.061$ & $9.440 \pm 3.059$ & $10.037 \pm 3.902$ & $11.057 \pm 3.055$ & $9.938 \pm 2.182$ & $10.962 \pm 1.155$ & $9.512 \pm 1.973$ \\
\hline Lymphocytes (\%) & $85.33 \pm 2.028$ & $88.603 \pm 3.093$ & $89.33 \pm 1.856$ & $81.33 \pm 2.741$ & $85.33 \pm 3.528$ & $79.520 \pm 2.741$ & $85.67 \pm 2.963$ & $81.530 \pm 3.074$ \\
\hline Monocytes (\%) & $7.830 \pm 0.5774$ & $5.045 \pm 0.702$ & $5.830 \pm 0.7386$ & $6.726 \pm 0.7607$ & $7.670 \pm 0.6667$ & $4.684 \pm 0.475$ & $7.749 \pm 0.573$ & $7.573 \pm 0.450$ \\
\hline
\end{tabular}




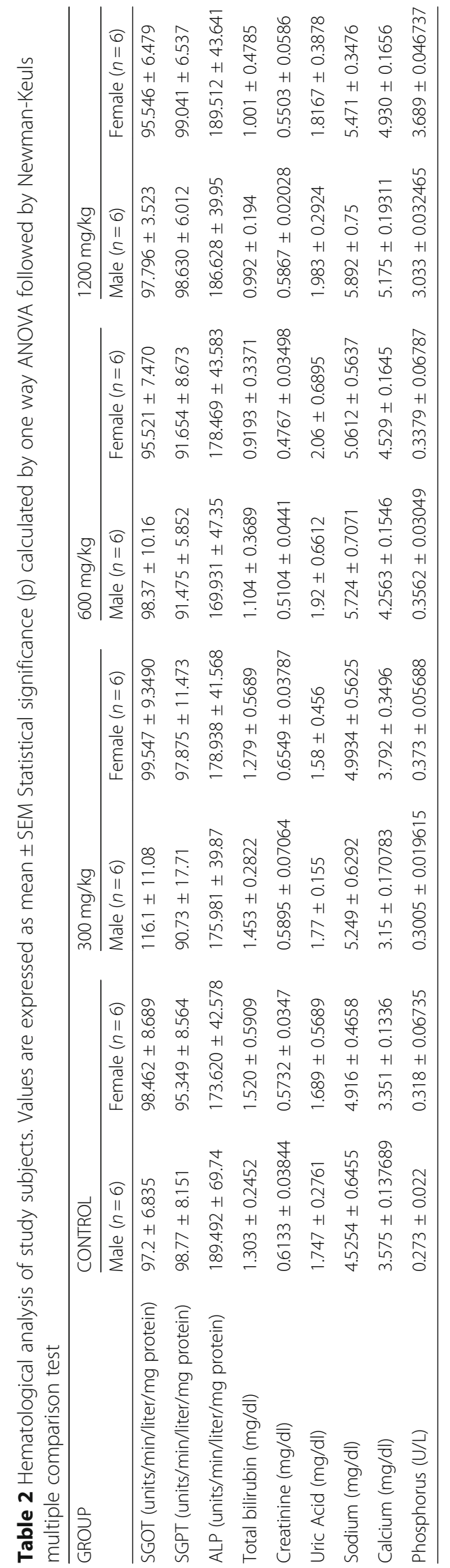



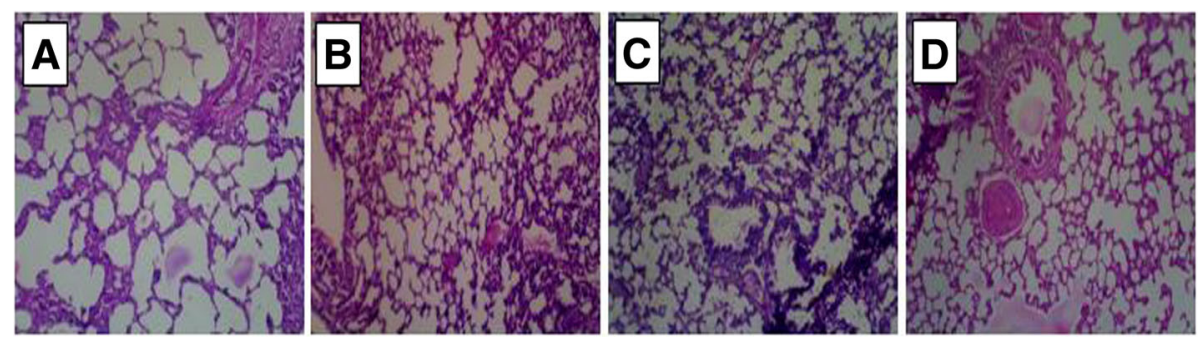

Fig. 9 Histopathological analysis of lung tissue in various concentration. a: Control group, b: Low dose (300 mg/kg), c: Mild dose (600 mg/kg), d: High dose $(1200 \mathrm{mg} / \mathrm{kg})$

Male subjects as well as female subjects treated with STRE up to $1200 \mathrm{mg} / \mathrm{kg}$ of body weight did not possess any kind of clinical toxicological signs referring to the uniformity that with untreated subjects.

\section{Investigation of biochemical parameters}

Any distinguished changes in biochemical parameters were not observed between untreated animals and treated animals (Table 2) all the parameters such as SGOT, SGPT, ALP, total bilirubin, creatinine, uric acid, Sodium, Calcium, and Phosphorus did not show any significant relationship that with STRE administrated where all the groups exhibited similar tendency.

\section{Investigation of histopathological parameters}

Study upon tissue histology of organs like lungs, liver, kidneys, spleen revealed the compatibility of Solanum torvum root extracts in study animals. Lung histology of subject treated with $300 \mathrm{mg} / \mathrm{kg}$ of body weight revealed normal alveoli, bronchi and bronchioles and mild lymphocytic infiltration in interstitium shows mild lymphocytic infiltrates however subjects administrated with 600 and $1200 \mathrm{mg} / \mathrm{kg}$ body weight showed mild inflammation in peribronchioles region but there were no evidence of toxic changes (Fig. 9). Photomicrographs of liver histology exposed the effect of STRE in study animals (Fig. 10) wherein section studied from the liver of subject treated with $300 \mathrm{mg} /$ $\mathrm{kg}$ showed normal lobular architecture with a mild dilation of sinusoids and mild inflammation in portal tract. Subject treated with mild dose displayed normal lobular architecture and mild dilation of central vein shows however normal lobular architecture was displayed by high dose treated subject. All groups showed same kidney histology with normal cortex and medulla. The glomeruli and tubulo interstitial compartments showed normal morphology with no evidence of inflammation or tubular necrosis noted (Fig. 11). Similarly spleen histology also suggested that the administrated drug is not inducing any toxic reaction in study animal where spleen sections of study groups exhibited normal white pulp and red pulp morphology (Fig. 12).

\section{Discussion}

The exploitation of plants and plant derived compounds have gained much importance in medical biotechnology as it open up to endless opportunities of drug discovery due to bioavailability and biocompatibility [22]. Solanum torvum have been used for its medicinal application as it posses analgesic, anti-inflammatory, Anti-ulcerogenic [23], blood pressure regulation [24], quorum sensing inhibition and immunomodulatory effects [25]. In spite of several biological applications there are no any data or reports regarding the toxicological
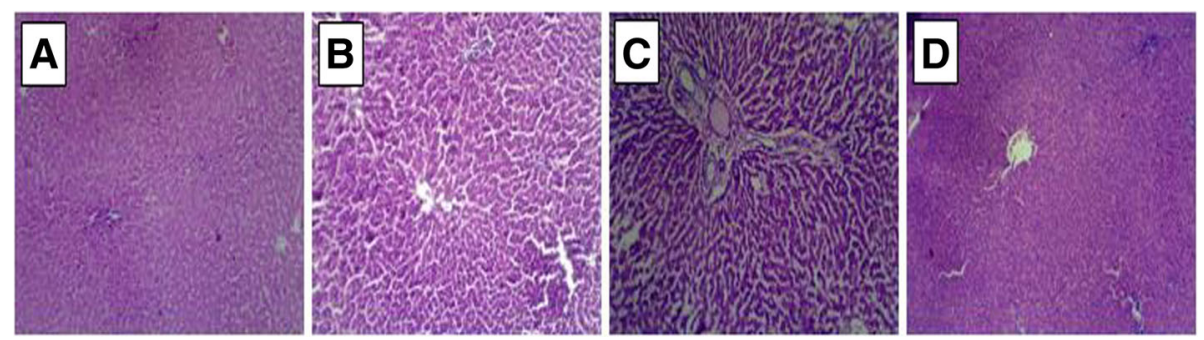

Fig. 10 Histopathological analysis of liver tissue in various concentration. a: Control group, b: Low dose (300 mg/kg), c: Mild dose (600 $\mathrm{mg} / \mathrm{kg})$, d: High dose $(1200 \mathrm{mg} / \mathrm{kg})$ 

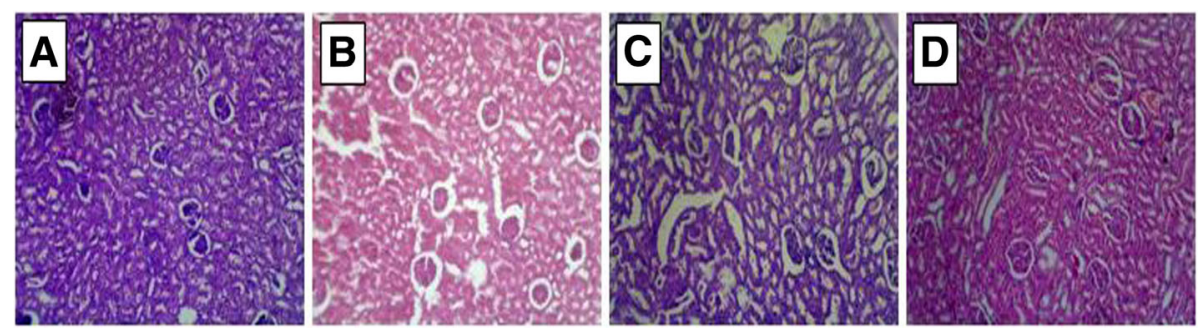

Fig. 11 Histopathological analysis of kidney tissue in various concentration. a: Control group, b: Low dose (300 mg/kg), c: Mild dose (600 mg/kg), d: High dose $(1200 \mathrm{mg} / \mathrm{kg})$

effects or safety analysis of the same. However Solanum torvum root extracts contains several flavonoids and tannins which may have some hazardous activities [26] therefore it is essential to analyze the toxicological properties of Solanum torvum root extract. In this study several parameters such as mortality, bodyweight regulation, hematological analysis, histological and biochemical parameters were analyzed to investigate the acute and sub-acute toxicity of STRE.

All the study subjects were active after the study period which indicates that there is no any significant relationship between mortality and dose response. However study animals being alive after study period indicates the compatibility of STRE as mortality is an important parameter to evaluate toxicity [27]. Similarly several ethnobotanical drugs exhibited null effects upon animal mortality such as leaf extract of Moringa oleifera Lam. (Moringaceae) [28] and aqueous extract of the leaves of Myrianthus arboreus P. Beauv. (Cecropiaceae) in toxicity studies in Wistar rats [29]. Likewise variations in body weight would indicate physiological alterations in hormonal activities, liver functioning, reduced protein metabolism etc. [30], however there were no changes in body weight between treated subjects and untreated subjects. It was also evident that there are no any significant relationship between concentrations of STRE administrated that with relative organ weight. This indicate that extract did not induce any kind of xenobiotic enzyme activity or elevation of protein synthesis in study animal [31]. Similar propensity was previously observed in aqueous extract of the leaves of Herniaria glabra in rodents [32] where extract did not induce any changes in relative organ weight.

Biochemical and histological analysis were done to understand the effect of STRE upon functions of organs such as lungs, liver, kidney and spleen which suggested that extract did not alter appropriate functioning of organs. SGOT, SGPT, ALP, total bilirubin levels were unaffected by various dose of extract administrated that indicates smooth functioning of liver [33]. Likewise analysis of creatinine, uric acid, Sodium, Calcium, and Phosphorus were performed to find about any adverse effect of STRE in kidney functioning. Kidney is the primary target of toxins as it receives one fourth of total cardiac blood flow [34], where in current study the administrated STRE was not jeopardizing kidney functions. Photomicrographs of tissue histology suggested that there were no any alterations in the tissue level organization of lungs, liver, kidney and spleen which proves the safety level of STRE when treated in various concentrations. Observations were matching with similar toxicity assessment reports of ethanolic extract of Pericampylus glaucus (Lam.) Merr. in BALB/c mice [35] and hydroethanolic extract of Dolichandra unguis-cati L. leaves in rats [36].

\section{Conclusion}

The acute and sub-acute toxicological analysis of Solanum torvum root extracts up on Wister rats suggested that there are no any dose response relation
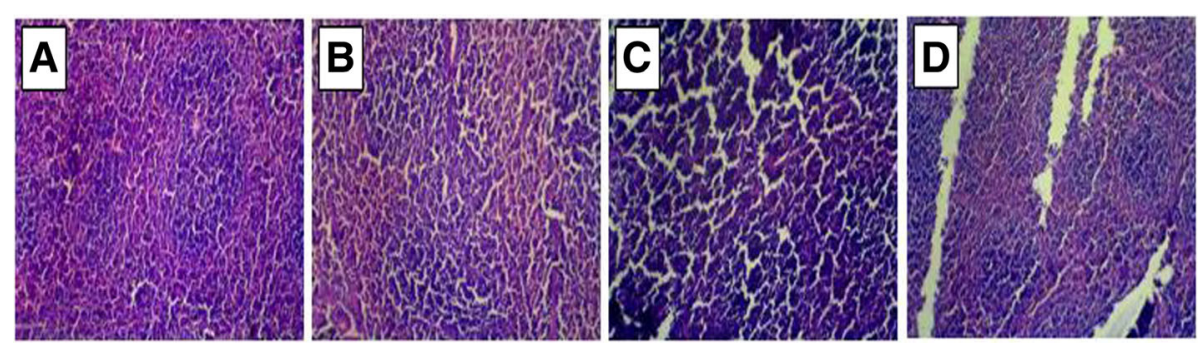

Fig. 12 Histopathological analysis of spleen tissue in various concentration. a: Control group, b: Low dose (300 mg/kg), c: Mild dose (600 mg/kg), d: High dose $(1200 \mathrm{mg} / \mathrm{kg})$ 
between extract administrated and toxicity, therefore there are no toxic effect by STRE, however more enlightenment regarding toxicity due to prolonged exposure can only be understood from chronic toxicity analysis.

\section{Acknowledgements}

I would like to acknowledge Bioresource Technology Lab, Department of Biotechnology, Thiruvalluvar University, India. KMCH, Coimbathore, TN, India and Marian Centre for Advanced research, St.Mary's College Thrissur, Kerala, India for the infrastructure support

\section{Funding}

This research did not receive any specific grant from funding agencies in the public, commercial, or.

Not-for-profit sectors.

\section{Availability of data and materials}

The identification details of source plant and the related data have been submitted in NCBI under the accession number KU599936.

\section{Authors' contributions}

The research was conceived and conducted by sole author Dr. Kayeen Vadakkan. The author read and approved the final manuscript.

\section{Ethics approval}

The experimental protocol was approved by Institutional Animal Ethical Committee (KMCRET/Ph.D./17/2017-17, dated 28-May-2016) as per the guidance of Committee for the Purpose of Control and Supervision of Experiments on Animals (CPCSEA), Ministry of Environment and Forest, government of India.

\section{Consent for publication}

Being the solitary author I hereby declare my approval for publishing the article entitled "Acute and sub-acute toxicity study of bacterial signaling inhibitor Solanum torvum root extract in Wister rats" in Clinical Phytoscience.

\section{Competing interests}

The authors declare that they have no competing interests.

\section{Publisher's Note}

Springer Nature remains neutral with regard to jurisdictional claims in published maps and institutional affiliations.

Received: 17 October 2018 Accepted: 15 April 2019

Published online: 01 May 2019

\section{References}

1. Araújo MC de PM, Barcellos NMS, Vieira PM, Gouveia TM, Guerra MO, Peters VM, et al. Acute and sub chronic toxicity study of aqueous extract from the leaves and branches of Campomanesia velutina (Cambess) O. Berg. J Ethnopharmacol [Internet]. Elsevier Ireland Ltd; 2017;201(February):17-25. Available from: https://doi.org/10.1016/j.jep.2017.02.043

2. Chah K, Muko K, Oboegbulema S. Antimicrobial activity of methanolic extract of Solanum torvum fruit. Fitoterapia. 2000;71(2):187-9.

3. Wannasiri S, Chansakaow S, Sireeratawong S. Effects of Solanum torvum fruit water extract on hyperlipidemia and sex hormones in high-fat fed male rats. Asian Pac J Trop Biomed Elsevier BV. 2017;7(5):401-5.

4. Rahmatullah M, Jahan Mukti I, Fahmidul Haque A, Ariful Haque M, Parvin K, Jahan $\mathrm{R}$, et al. An ethnobotanical survey and pharmacological evaluation of medicinal plants used by the Garo tribal community living in Netrakona district, Bangladesh. Nat Appl Sci Adv Nat Appl Sci. 2009;3(33):402-18.

5. Vadakkan K, Vijayanand S, Choudhury AA, Gunasekaran R, Hemapriya J. Optimization of quorum quenching mediated bacterial attenuation of Solanum torvum root extract by response surface modelling through boxBehnken approach. J Genet Eng Biotechnol. 2018.

6. Waters CM, Bassler BL. Quorum sensing : communication in Bacteria. Annu Rev Cell Dev Biol. 2005;21(1):319-46.
7. Rutherford ST, Bassler BL. Bacterial quorum sensing: its role in virulence and possibilities for its control. Cold Spring Harb Perspect Med. 2012;2(11).

8. Papenfort K, Bassler B. Quorum-sensing signal-response Systems in GramNegative Bacteria. Nat Rev Microbiol. 2016;14(9):576-88.

9. Chen F, Gao Y, Chen X, Yu Z, Li X. Quorum quenching enzymes and their application in degrading signal molecules to block quorum sensingdependent infection. Int J Mol Sci. 2013;14(9):17477-500.

10. Torres M, Uroz S, Salto R, Fauchery L, Quesada E, Llamas I. HqiA, a novel quorum-quenching enzyme which expands the AHL lactonase family. Sci Rep. 2017;7:943.

11. Basavaraju M, Sisnity VS, Palaparthy R, Addanki PK. Quorum quenching: signal jamming in dental plaque biofilms. J Dent Sci Elsevier Taiwan LLC. 2016:11(4):349-52.

12. Algandaby MM. Assessment of acute and subacute toxic effects of the Saudi folk herb Retama raetam in rats. J Chinese Med Assoc [Internet]. Elsevier Taiwan LLC and the Chinese Medical Association; 2015;78(12):691701. Available from: https://doi.org/10.1016/j.jcma.2015.06.011

13. Manaharan T, Chakravarthi S, Radhakrishnan AK, Palanisamy UD. In vivo toxicity evaluation of a standardized extract of Syzygium aqueum leaf. Toxicol reports [internet]. The Authors; 2014;1:718-725. Available from: https://doi.org/10.1016/j.toxrep.2014.09.006

14. Tchoumtchoua J, Mouchili OR, Ateba SB, Zingue S, Halabalaki M, Mbanya JC, et al. Safety assessment of the methanol extract of the stem bark of Amphimas pterocarpoides harms: acute and subchronic oral toxicity studies in Wistar rats. Toxicol Reports. 2014;1:877-84.

15. Da Silva RO, Andrade VM, Bullé Rêgo ES, Azevedo Dória GA, Santos Lima B Dos, Da Silva FA, et al. Acute and sub-acute oral toxicity of Brazilian red propolis in rats. J Ethnopharmacol [Internet]. Elsevier; 2015;170:66-71. Available from: https://doi.org/10.1016/j.jep.2015.05.009

16. Ameni AZ, Latorre OA, Torres LMB, Górniak SL. Toxicity study about a medicinal plant Casearia sylvestris: A contribution to the Brazilian Unified Health System (SUS). J Ethnopharmacol [Internet]. Elsevier; 2015:175:9-13. Available from: https://doi.org/10.1016/j.jep.2015.08.027

17. Gopi S, Jacob J, Mathur KY. Acute and subchronic oral toxicity studies of hydrogenated curcuminoid formulation 'CuroWhite' in rats. Toxicol reports [internet]. Elsevier Ireland Ltd. 2016:3:817-25. Available from:. https://doi.org/ 10.1016/j.toxrep.2016.10.007.

18. Traesel GK, de Souza JC, de Barros AL, Souza MA, Schmitz WO, Muzzi RM, et al. Acute and subacute ( 28 days) oral toxicity assessment of the oil extracted from Acrocomia aculeata pulp in rats. Food Chem Toxicol [Internet]. Elsevier Ltd; 2014;74(September 2013):320-325. Available from: https://doi.org/10.1016/j.fct.2014.10.026

19. Silva MGB, Aragão TP, Vasconcelos CFB, Ferreira PA, Andrade BA, Costa IMA, et al. Acute and subacute toxicity of Cassia occidentalis L. stem and leaf in Wistar rats. J Ethnopharmacol [Internet]. Elsevier Ireland Ltd; 2011;136(2): 341-346. Available from: https://doi.org/10.1016/j.jep.2011.04.070

20. Imafidon KE, Egberanmwen ID, Omoregie IP. Toxicological and biochemical investigations in rats administered "kaun" (trona) a natural food additive used in Nigeria. J Nutr Intermed Metab. 2016;6:22-5.

21. Olaniyan JM, Muhammad HL, Makun HA, Busari MB, Abdullah AS. Acute and subacute toxicity studies of aqueous and methanol extracts of Nelsonia campestris in rats. J Acute Dis [Internet] Elsevier (Singapore) Pte Ltd. 2016;5(1):62-70 Available from: http://inkinghub.elsevier.com/retrieve/pii/S2221618915000888.

22. Miller JS. The global importance of plants as sources of medicines and the future potential of Chinese plants. In: Drug discovery and traditional Chinese medicine; 2001. p. 33-42.

23. Nguelefack TB, Feumebo C, Ateufack G, Watcho P, Tatsimo S, Atsamo AD, et al. Anti-ulcerogenic properties of the aqueous and methanol extracts from the leaves of Solanum torvum Swartz (Solanaceae) in rats. J Ethnopharmacol. 2008;113(1):135-40.

24. Mohan M, Jaiswal BS, Kasture S. Effect of Solanum torvum on blood pressure and metabolic alterations in fructose hypertensive rats. J Ethnopharmacol. 2009;126(1):86-90

25. Koffuor GA, Amoateng P, Andey T. Immunomodulatory and erythropoietic effects of aqueous extract of the fruits of Solanum torvum Swartz (Solanaceae). Pharm Res. 2011;3(2):130-40.

26. Stich HF. The beneficial and hazardous effects of simple phenolic compounds. Mutat Res Toxicol. 1991:259(3-4):307-24.

27. Asarea GA, Gyan B, Bugyei K, Adjei S, Mahama R, Addo P, et al. Toxicity potentials of the nutraceutical Moringa oleifera at supra-supplementation levels. J Ethnopharmacol. 2012;139(1):265-72. 
28. Awodele O, Oreagba IA, Odoma S, Teixeira da Silva JA, Osunkalu VO. Toxicological evaluation of the aqueous leaf extract of Moringa oleifera lam. (Moringaceae). J Ethnopharmacol [Internet]. 2012;139(2):330-6. Available from: http://www.sciencedirect.com/science/article/pii/S0378874111007355.

29. Awounfack CF, Ateba SB, Zingue S, Mouchili OR, Njamen D. Safety evaluation (acute and sub-acute studies) of the aqueous extract of the leaves of Myrianthus arboreus P. Beauv. (Cecropiaceae) in Wistar rats. J Ethnopharmacol [Internet]. 2016;194:169-78 Available from: http:/www. sciencedirect.com/science/article/pii/S0378874116306079.

30. Lee M-Y, Shin I-S, Seo C-S, Kim J-H, Han S-R, Shin H-K. Subchronic oral toxicity studies of the traditional herbal formula Bangpungtongseong-san in Crl: CD (SD) rats. J Ethnopharmacol [Internet]. 2012;144(3):720-5 Available from: http://www.sciencedirect.com/science/article/pii/S0378874112006915.

31. Diallo A, Eklu-Gadegbeku K, Amegbor K, Agbonon A, Aklikokou K, Creppy E, et al. In vivo and in vitro toxicological evaluation of the hydroalcoholic leaf extract of Ageratum conyzoides L. (Asteraceae). J Ethnopharmacol [Internet]. 2014;155(2):1214-8 Available from: http://www.sciencedirect.com/science/ article/pii/S0378874114005091.

32. Rhiouani H, El-Hilaly J, Israili ZH, Lyoussi B. Acute and sub-chronic toxicity of an aqueous extract of the leaves of Herniaria glabra in rodents. $J$ Ethnopharmacol [Internet]. 2008;118(3):378-86 Available from: http://www. sciencedirect.com/science/article/pii/S0378874108002456.

33. Malaguarnera G, Cataudella E, Giordano M, Nunnari G, Chisari G, Malaguarnera M. Toxic hepatitis in occupational exposure to solvents. World J Gastroenterol. 2012;18(22):2756-66.

34. Kataria A, Trasande $L$, Trachtman $\mathrm{H}$. The effects of environmental chemicals on renal function. 2015;11(10):610-625.

35. Kifayatullah M, Mustafa MS, Sengupta P, Sarker MMR, Das A, Das SK. Evaluation of the acute and sub-acute toxicity of the ethanolic extract of Pericampylus glaucus (Lam.) Merr. in BALB/c mice. J Acute Dis [Internet]. Elsevier (Singapore) Pte Ltd; 2015;4(4):309-315. Available from: http:// linkinghub.elsevier.com/retrieve/pii/S2221618915000517.

36. Calil Brondani J, Reginato FZ, da Silva Brum E, de Souza Vencato M, Lima Lhamas C, Viana C, et al. Evaluation of acute and subacute toxicity of hydroethanolic extract of Dolichandra unguis-cati L. leaves in rats. J Ethnopharmacol [Internet]. 2017;202:147-153. Available from: http://www. sciencedirect.com/science/article/pii/S037887411630808X.

\section{Submit your manuscript to a SpringerOpen ${ }^{\circ}$ journal and benefit from:}

- Convenient online submission

- Rigorous peer review

- Open access: articles freely available online

- High visibility within the field

- Retaining the copyright to your article

Submit your next manuscript at $\boldsymbol{\nabla}$ springeropen.com 